\title{
Medico-Legal Updates of the Adverse Threat of Cigarette Advertisements on Children
}

\author{
Bambang Eko Turisno ${ }^{1}$, IGA Gangga Santi Dewi ${ }^{1}$, Suharto ${ }^{1}$, Ery Agus Priyono ${ }^{1}$ \\ ${ }^{1}$ Lecturer at Faculty of Law, Diponegoro University, Indonesia
}

\begin{abstract}
Advertising is an integral part of modern business activities. Information on ad serving in the form of true, clear and honest information about the condition and guarantee of goods is a consumer right that must be given by business actors. In Indonesia, cigarette advertisements in laws and regulations limit and provide several conditions. Some cigarette advertisements do not meet the conditions. The results showed that cigarette advertisements include, visual, tagline, images, placement, airtime, and content of advertisements using psychological persuasion, targeting the share of adolescents and children, who play a role in the onset of cigarette use, encouraging young people to start smoking that threatens children and teenagers.
\end{abstract}

Keywords: Medico-legal aspects, cigarette, advertisements, adverse effect, children.

\section{Introduction}

Advertising is an inseparable part of modern business. This fact is closely related to the way of modern industrial production which produces products in large quantities, so it must find a buyer. Advertising primarily intends to provide information on the products produced that are expected to be effective, so that products or services are in demand in the market. Gov. Reg No. 19/2003 concerning Amendments to Gov. Reg No.81 of 1999 concerning Safeguarding Cigarettes for Health, stated that cigarette advertising is an activity to introduce, promote cigarettes with or without rewards to the public with the aim of influencing consumers to use the cigarettes offered. Advertising can be divided into two functions, namely the informative function and the persuasive function. In reality there are no ads that are merely informative and no ads that are merely persuasive.

\section{Corresponding Author:}

\section{Bambang Eko Turisno}

Lecturer at Faculty of Law, Diponegoro University, Jl. Prof. Soedarto, Tembalang, Semarang, Central Java 50275, Indonesia

e-mail: bambangekoturisno@live.undip.ac.id
However, there are advertisements with more dominant information elements, and advertisements with the most striking promotional elements. Providing true, clear, and honest information about the conditions and guarantees of goods and/or services as well as providing an explanation of the use, repair and maintenance specified in Article 7 (b) of the Consumer Protection Act is the obligation of business actors. Information that is true, clear, and honest about the conditions and guarantees of goods and/or services according to Article 4.1 is the consumer's right. Business actors have the obligation as stipulated in Article 7 to have a good intention in carrying out their business activities.

Cigarette advertising can only be done with certain requirements. The public knows that smoking can have negative effects, although on the other hand some people still consume it. The prevalence of active smokers in Indonesia is increasing very fast. Cigarettes contain an addictive substance which if inhaled can endanger health for individuals and society. Each cigarette contains nicotine and tar which are substances, compounds or substances that are addictive and carcinogenic.Forms of cigarette advertisements are widely displayed on billboards, print media and television media. A number of cigarette advertisements, targeting the share of teenagers and children, groups of children and adolescents are very vulnerable to advertisements because they can create 
models that are imitated and form inappropriate dreams. Advertising, promotion, production requirements and sales of cigarettes, the settings have not been determined to the maximum. The study discusses the protection of children in cigarette advertisements which include, how the contents of cigarette advertisement loading in Indonesia and how children protect against cigarette advertisements.

Research Method: The approach method used is classified as empirical juridical and analytical descriptive research specifications, and qualitative analysis is also used. Data collection includes records, documents, articles and clippings from the mass media as well as data obtained by looking at the legislation and relevant literature. The data was also obtained directly through observations in the field observations, which were carried out directly at the research location which included brochures, banners, cigarette billboards, and cigarette advertisements on television.

Cigarette Advertisements in Indonesia: Most countries impose regulations on advertising practices. In general, industry regulations and laws in many countries are aimed at protecting companies from unfair competitive attacks ${ }^{1}$. Regulation is also to protect consumers against false and misleading advertising. Consumers must be protected from wrong business practices and their ignorance. Promotional activities according to Article 1.6 Law No. 8/1999 concerning Consumer Protection as an activity for introducing or disseminating information on goods and/or services to attract consumers to buy goods and/or services to be traded, is giving obligations to business actors in Article 7 to have an intention good at doing business. Obligations of business actors specified in Article 7 (b), namely to provide true, clear and honest information about the conditions and guarantees of goods and/or services and to provide explanations for the use, repair and maintenance. Information that is true, clear, and honest about the conditions and guarantees of goods and/ or services according to Article 4.1 is the consumer's right.

In Indonesia, the advertising material as Article 17 Gov. Reg. No. 19 of 2003 concerning Amendments to Gov. Reg. No. 81 of 1999 concerning Safeguarding Cigarettes for Health determines that it is prohibited to stimulate or encourage people to smoke, illustrate or suggest that smoking provides health benefits, display or illustrate in the form of pictures, writing or a combination of both, cigarettepackets, cigarettes or people who are smoking or point to people who are smoking, aimed at or displaying in the form of pictures or writing or a combination of both, children, adolescents, or pregnant women, to name the product concerned of cigarettes, and be contrary to the norms prevailing in society.

Cigarette advertisements and protection for children: A report from the US Department of Health and Human Services shows that if a person does not start smoking until past the age of adolescence, he will not start smoking. of the adults who had smoked, $88 \%$ lit their first cigarette at the age of 18 , and more than $44 \%$ were accustomed to smoking at that age. Some studies demonstrated that the younger a person starts smoking, the higher the likelihood of someone becoming a heavy smoker $^{2,3,4}$. Furthermore,Bezilla, George and Gallup International Foundation show that seventy percent of teenagers who smoke regret their decision and $66 \%$ want to quit smoking 5 .

Cigarette marketing is important to encourage young people to start smoking ${ }^{6,7}$. Teinowitzstated that exposure to advertisements and other forms of marketing communication played a role in the beginning of the use of tobacco products and $90 \%$ of smoking habits started with teenagers, according to the Institute of Health and Human Services in his research. The results of a Pollay et al, showed that brand advertising significantly influences brand selection, especially in young people ${ }^{8}$. Tobacco brands are more often associated with positive images than producer names. Advertising spending to increase market share is dedicated to developing brand identification and preferences rather than developing producer identification. Consumers identify and buy tobacco products through brand names instead of producer name. A number of cigarette advertisements, targeting the share of teenagers and children, not adults. The selection of media and inappropriate broadcast time tagged a number of cigarette advertisements including 'just enjoy it, and, 'no you are not crowded', targeting the share of teenagers and children, not adults. Therefore cigarette advertising is considered detrimental to children and adolescents. Cigarette advertisements display cigarette brands by including the price of cigarettes per stick, the aim is to make it easier for children to calculate the money they have to buy cigarettes.

Groups of children and adolescents are very vulnerable because advertising can create models that are imitated and form inappropriate dreams. As a visual 
media, television can show something that creates a false impression through optical illusions or similar means. The strength of TV is the demonstration ability. This TV is a champion in marketing, because this media allows people to see products or services plus the demo, in an easy way. Delivered in an advertisement, one of the functions of cigarettes is to show males. Cigarettes are a man's male identity ${ }^{9}$. With a cigarette he feels as male as a cowboy warrior, while riding a gallant horse or associated with super busy executive work while inhaling puffs of smoke that are said to contain nuclear material. Cigarette advertisements featuring masculinity as illustrated in a contest of courage through adventure. As a result, men want to smoke to the point of smelling to show their masculinity, the assumption will be awesome when smoking. The creation of psychological consumer desires, one's desire for goods that "makes him feel personal achievement, promises social acceptance". According to John K. Galbraith, quoted by Velasquez is a manipulative advertisement ${ }^{10}$.

Warning of the dangers of smoking contained in cigarette advertisements, Fox et al, put forward some of the results of the study as follows ${ }^{7}$. First, Pollayand Strasburger et al,research cited young people as being far more sensitive to advertising than adults ${ }^{11,12}$. Young people are easily persuaded by display ads, which are used extensively in advertising tobacco products. The nature of youth makes teenagers more sensitive than other age groups to advertising parables and promotion appeal. Many brand loyalties, according to Raphael, started in adolescence and surviving into adulthood ${ }^{13}$. Research from Beltramini on cigarette warnings shows that adolescents are less trustworthy ${ }^{14}$. According to Maluoff et al, it requires a high level of reading comprehension ${ }^{15}$. Teenagers tend to underestimate the risk of using dangerous products. Laventhal et al, research proves that adolescents tend to underestimate the dangers of smoking and overestimate smoking excess ${ }^{16}$. Teenagers see themselves as immune to the negative effects of smoking, according to Fischer et al,young people also have difficulty connecting the negative impacts that can occur in the future ${ }^{17}$. General provisions of Gov. Reg. No.19 of 2003 concerning Amendments to Gov. Reg. No. 81 of 1999 concerning Safeguarding Cigarettes for Health require cigarette labels, i.e. any information about cigarettes in the form of pictures, writing, a combination of both, or other forms included in cigarettes, put in, placed on, or are part of cigarette packaging.
Regarding advertising about products that are detrimental to public health, the government can limit or even ban ${ }^{18}$. In the United States, Fox et al,who quoted Teinowitzeven though no central regulations were applied to tobacco product advertising, the local government began to take action ${ }^{7,8}$. Tobacco advertising is prohibited on billboards in the Baltimore are. Baltimore regional regulations forbidding the placement of any signs from cigarette advertisements in publicly visible locations, such as billboards, building sides, and free standing signage ${ }^{2}$.

In 1965 the cigarette warning was adopted in the United States. Cigarette warnings are one of the most widespread uses of explanation disclosure ordered by central policy and help the role of government policy in warning consumers of the dangers of smoking 7 . Warn adolescents can prove difficult. The nature of adolescence makes dependence on tobacco, making stopping smoking a very difficult thing to do later. Warning of statistics and the increasing amount of evidence of increased smoking rates in adolescents, President Clinton proposed steps to reduce smoking rates in adolescents. One such step is to further limit advertising. On August 10, 1995, President Clinton, as Press issued by the White House 1995 page 1, announced a six-step plan to limit "advertisement, promotion, distribution and marketing of cigarettes for teenagers." First, teens must prove their age with an identity card to buy cigarettes. Second, automatic sales machines will be banned. Third, smokeless cigarette or tobacco billboards near playgrounds or schools will be banned. Fourth, pictures will not appear on billboards outside the room or in advertisements noticed by many teenage audiences. Fifth, marketing to teenagers is prohibited, and the prohibition includes items ranging from selling single cigarettes, T-shirts and sports bags to sponsoring sports activities. Sixth, through education efforts, the tobacco industry must fund and implement an annual \$ 150 million campaign aimed at stopping teenagers from smoking ${ }^{2}$.

If we see in the United States there is an institution called the Federal Trade Commission (FTC) which has been involved in the continuous supervision and marketing practice of cigarette advertising, starting in the early 1940s. Cigarette advertising in the United States is more limited than other legitimate consumer products. Some regulations are mainly information (warning labels), while others affect the level of direct advertising (broadcast ban). Over a period of six decades, the FTC governed the overall direction of cigarette 
marketing, including content advertising and placement, label warnings, and product development. Through the testing program, he is able to influence the types of cigarettes produced and consumed. The FTC is involved in monitoring the practice of cigarette advertisements and preparing in-depth reports on these practices. It was held with opinions on cigarette testing, advertising, and labeling, and published consumer smoking advisories. Directly or indirectly, the FTC has begun or influenced the promotion and development of products in the cigarette industry ${ }^{19}$. The Federal Trade Commission (FTC) has the power to regulate "dishonest and deceptive business practices," including advertisements for food and drugs. With the section on the 1967 State Law on Cigarette Labels and Ads Congress has authorized the FTC to enforce restrictions on cigarette advertising and report to Congress once a year in relation to smokeless tobacco and tobacco advertising, including recommendations for further restrictions by the agency believed to be enacted by Congress ${ }^{2}$.

\section{Conclusion}

In Indonesia, cigarette advertising is limited by several requirements, but cigarette advertising is actually more liberal and unethical. Some cigarette advertisements are illogical and misleading. Advertisers use psychological persuasion, which advertisers are aiming for is not the use of reason by users or potential users but human emotions. Manipulative cigarette advertisements create desires in consumers who are psychological. Many cigarette advertisements do not meet the conditions. Violations at the time of display of cigarette advertisements on electronic media also on the prohibition to display advertisements for the appearance of cigarettes and or the use of cigarettes.

Cigarette ads target the share of teenagers and children. Cigarette advertisements encourage young people to start smoking which harms children and adolescents. Advertising plays a role in the initial use of tobacco products. Cigarette advertisements harm teenagers and children. To reduce smoking rates in teenagers, it is necessary to limit cigarette advertising. The beginning of the use of tobacco products by teenagers needs to be prevented. Cigarette marketing, including advertising to adolescents besides being prohibited, education efforts need to be made that the tobacco industry must fund and implement campaigns aimed at stopping youth from smoking.
Suggestion: Limiting cigarette advertisements for teenagers in addition to promotion, distribution and marketing. Reducing smoking rates in teenagers. Institutions that regulate, supervise and sanction the overall direction of cigarette marketing, including advertisements, are needed. Censored before airing on television and mass media as well as continuous monitoring of cigarette advertising practices. Local regulations should prohibit the placement of any sign of cigarette advertisements in a publicly visible location and monitor the content of advertisements on billboard advertisements.

Ethical Clearance: This research was ethically approved by Faculty of Law, Universitas Diponegoro, Semarang, Indonesia

Funding: This research receives Research Grant Funds at the Faculty of Law of Diponegoro University in the 2020 budget year.

Conflict of Interests: There are no conflict of interests

\section{References}

1. Simamora, H. Manajemen Pemasaran. Jakarta, Penerbit Salemba Empat; 2010.

2. Petty RD, McKay SE, Dundas MJ, Yeargain JW. The FDA's proposed rules regulating tobacco and underage smoking and the commercial speech doctrine. Journal of Public Policy \& Marketing. 1996 Sep;15(2):296-303.

3. Escobedo LG, Reddy M, Giovino GA. The relationship between depressive symptoms and cigarette smoking in US adolescents. Addiction. 1998 Mar 1;93(3):433.

4. Taioli E, Wynder E. Effect of the age at which smoking begins on frequency of smoking in adulthood. The New England Journal of Medicine. 1991 Sep 26;325(13):968-9.

5. Bezilla R, George H. Gallup International Foundation, United States of America. Teen-Age Attitudes and Behavior Concerning Tobacco: Report of the Findings. Princeton, NJ: George H. Gallup International Institute. 1992.

6. Hastings GB, Aitken PP. Tobacco advertising and children' s smoking: a review of the evidence. European Journal of Marketing. 1995 Nov 1. 
7. Fox RJ, Krugman DM, Fletcher JE, Fischer PM. Adolescents' attention to beer and cigarette print ads and associated product warnings. Journal of advertising. 1998 Oct 1;27(3):57-68.

8. Teinowitz I.Tobacco cases worry ad groups. Advertising Age. 2001;72(13):17-17.

9. Kartajaya H, Indrio BD, Madyani D. Marketing in venus. Gramedia Pustaka Utama; 2004.

10. Velasquez MG. Business ethics: Concepts and cases (Vol. 111). Upper Saddle River, NJ: Prentice Hall; 2002.

11. Pollay RW. The distorted mirror: Reflections on the unintended consequences of advertising. Journal of marketing. 1986 Apr;50(2):18-36.

12. Strasburger VC, Wilson BJ, Jordan AB. Children, adolescents, and the media. Sage Publications; 2013 Mar 14.

13. Raphael M. Are you kidding?. Direct Marketing; 1993;56(3).

14. Beltramini RF. Perceived believability of warning label information presented in cigarette advertising. Journal of Advertising. 1988 Jun 1;17(2):26-32.
15. Malouff J, Gabrilowitz D, Schutte N. Readability of health warnings on alcohol and tobacco products. American Journal of Public Health. 1992 Mar;82(3):464-.

16. Leventhal H, Glynn K, Fleming R. Is the smoking decision an'informed choice'?: effect of smoking risk factors on smoking beliefs. Jama. 1987 Jun 26;257(24):3373-6.

17. Fischer S, Spiegelhalder B, Eisenbarth J, Preussmann R. Investigations on the origin of tobacco-specific nitrosamines $\mathrm{n}$ mainstream smoke of cigarettes. Carcinogenesis. 1990 May 1;11(5):723-30.

18. Kasali R. Manajemenperiklanankonsep dan aplikasinya di Indonesia. Pustaka Utama Grafiti; 1992.

19. Nelson J P. Advertising bans in the United States. EH. Net Encyclopedia;2004(1):29. 